\section{Different Cell Types Involved in Mediating Concanavalin A Induced Liver Injury: A Com- prehensive Overview}

\author{
Marlies Ballegeer ${ }^{1}$ and Claude Libert ${ }^{2 *}$ \\ ${ }^{1}$ Inflammation Research Center, VIB, Technologypark, Ghent, Belgium \\ ${ }^{2}$ Department of Biomedical Molecular Biology, Ghent University, Ghent, \\ Belgium
}

\begin{abstract}
Autoimmune Hepatitis (AIH) is a chronic liver disease where presentation of a self-antigen peptide by professional antigen presenting cells initiates liver damage and drives the differentiation of uncommitted CD4 helper T cells to a Th1 and Th17 response. However, the details of the pathogenic mechanisms remain unclear and current treatments stay non-specific, making the need for reliable animal models high. Due to the activation and recruitment of T lymphocytes to the liver, the Concanavalin A (ConA) model is a proper animal model to investigate most forms of acute liver injury in humans such as $\mathrm{AlH}$, acute liver failure and acute viral hepatitis in which T cell infiltration is observed. Intravenous injection of ConA leads to severe liver damage by necrotic cell death of hepatocytes and release of alanine and aspartate transaminases into the blood. In this review, we present an overview of the current understanding of the model, with an emphasis on the cell types involved in ConA-induced liver injury.

Keywords: Cell types; Hepatitis; Mechanism; Therapy
\end{abstract}

\section{Abbreviations}

ALF: Acute Liver Failure

AIH: Autoimmune Hepatitis

ConA: Concanavalin A

GalN: D Galactosamine

HSCs: Hepatic Stellate Cells

KCs: Kupffer Cells

LSECs: Liver Sinusoid Endothelial Cells

MDSCs: Myeloid Derived Suppressor Cells

MHC: Major Histocompatibility

ROS: Reactive Oxygen Species

\begin{abstract}
*Corresponding author: Claude Libert, Inflammation Research Center, VIB, Technologypark, 927, 9052 Ghent, Belgium, Tel: +32 93313700; E-mail: Claude.Libert@IRC.VIB-UGent.be
\end{abstract}

Citation: Ballegeer M, Libert C (2016) Different Cell Types Involved in Mediating Concanavalin A Induced Liver Injury: A Comprehensive Overview. J Gastroenterol Hepatology Res 1: 001.

Received: March 05, 2016; Accepted: May 03, 2016; Published: May 18, 2016
SCID: Severe Combined Immunodeficiency Syndrome TCR: T-cell Receptor

\section{Key points}

- Concanavalin A (ConA) induced T cell infiltration and liver injury is a model for acute hepatitis

- Important cell types include most white blood cells as well as stromal cells

- The ConA model has successfully been used to discover new pathways in hepatitis research

- New therapeutic interventions for hepatitis were discovered using the ConA model

\section{Introduction}

\section{Autoimmune hepatitis}

Autoimmune Hepatitis (AIH) is a chronic liver disease associated with raised plasma liver enzymes like transaminases and the presence of autoantibodies [1,2]. The initial trigger of the disease is unknown but different genetic risk factors have been identified $[3,4]$. In general, it is believed that multiple perturbations, unidentified environmental factors or drugs and the loss of self-tolerance are needed for the onset and development of AIH. The mechanisms for loss of self-tolerance leading to auto reactivity remain unclear but major contributors such as impaired thymic negative selection and expansion of promiscuous $\mathrm{T}$ cell clones are suggested [5]. In AIH, presentation of a self-antigen peptide within a Major Histocompatibility (MHC) II molecule by professional Antigen Presenting Cells (APCs) initiates liver damage. This antigen presentation, in combination with exposure to various cytokines, drives the differentiation of uncommitted CD4 helper $\mathrm{T}$ cells and immune reaction that is skewed to a Th1 and Th17 response. However, the Th2 response cannot be ignored because it is important in the production of auto-antibodies, which trigger cellular cytotoxicity and complement activation [6,7]. The current standard treatment of AIH patients consists of non-specific immune suppressing drugs such as corticosteroids in combination with azathioprine, which leads to a decrease in serum aminotransferase levels [8].

\section{AIH animal models}

Despite extensive research on the pathogenesis of $\mathrm{AIH}$, the details of the mechanism remain elusive and the current treatments are non-specific and insufficient. The need for faithful and reliable animal models is therefore high. However, finding a suitable animal model is difficult due to the fact that AIH lacks a precise time of onset, etiological agent and the clinical phenotype is variable. According to Czaja et al., the current AIH models can be divided in two categories: the pathogenic and therapeutic models [1]. Pathogenic models focus on characterization of individual mechanisms contributing to occurrence and severity of the disease. In these perturbed models, individual pathways can be isolated and manipulated in a genetic homogenous background. Next to transgenic models in which target antigens are expressed under the control of liver-specific promoters, several inducible models such as the D Galactosamine (GalN) in com 
bination with lipopolysaccharide/enterotoxin hepatitis, and Concanavalin A (ConA) liver injury have been defined [9]. Despite the insights that can be gained with the pathogenic models, therapeutic models are needed to test new molecular interventions. These models require a consistent aggressive phenotype and close similarity to human disease. One of the major challenges in creating these models is the difficulty to lose self-tolerance due to the tolerogenic nature of the liver. In order to break this inherent tolerance, a preconditioning of the liver with an adjuvants or stimulators of the innate immune response might be needed. Recently, a new conditional knockout model deleting TNF Receptor Associated Factor (TRAF) 6 in medullary thymic epithelial cells and a transgenic CYP2D6 model using a natural human autoantigen to induce a long-term auto-immune damage to the liver were identified [10-12]. For a more elaborate overview of AIH animal models we refer to $[1,9,13,14]$. In this review we will focus on the ConA model of hepatitis as a well-established model to investigate $\mathrm{T}$ cell and macrophage dependent liver injury.

\section{ConA induced liver injury}

ConA is a plant lectin purified from Canavlia brasiliensis [15]. Lectins are proteins that bind to sugar residues on the surface of a wide variety of cell types, leading to agglutination of cells, mitogenic stimulation, or cytotoxicity of lymphocytes and macrophages [16]. ConA binds to the mannose receptor on Liver Sinusoidal Endothelial Cells (LSECs) early after administration (4 hours), leading to the breakdown of their membrane and subsequent cell death. At this time point, a pronounced sticking of leukocytes to the hepatic endothelium is also observed. Because of the detachment of LSECs, the binding of ConA to Kupffer Cells (KCs) and neutrophils is facilitated. Four hours later, CD4+ T lymphocytes are found attached to hepatocytes and are able to recognize MHC II molecules bound with ConA, leading to their activation. Eight hours after ConA, the sinusoidal parts of the hepatocytes show severe damage with ruptures of the cell membrane, membrane blebbing and loss of cytoplasm. The ConA model is mainly characterized by a Th1 response leading to extensive inflammation by elevated cytokine levels. Infiltration by cytotoxic $\mathrm{CD} 8+\mathrm{T}$ cells is a secondary event that results in hepatic apoptosis and eventually liver failure [17] (Figure 1). Intravenous ConA injection leads to an early hepatic cytokine storm with antigen independent activation and $\mathrm{T}$ cell proliferation. This results in severe liver damage by necrotic cell death of hepatocytes and release of transaminases Alanine Transaminase (ALT) and Aspartate Transaminase (AST) into the blood. Histopathological examination of the other major organs shows no obvious signs of organ injury except in the liver [17]. The ConA model is suitable for investigation of the involvement of $\mathrm{T}$ cell infiltration but also to study cytokines produced by $\mathrm{T}$ cells such as Tumor Necrosis Factor (TNF) and Interferon-Gamma $($ IFN- $\gamma)$ [18].

Despite the above differences between the ConA model and human $\mathrm{AIH}$, this model is considered as one of the best models for mimicking and studying certain mechanisms of $\mathrm{AIH}$, and it has played an important role in AIH drug development [9]. However, decades of ConA-induced hepatitis research demonstrate that the model suffers from substantial variability resulting in inconsistency of reported results. The most important factors to take into account when using this model are the dose, genetic background, gender and age of the mice and microbial status of the animal facility. For more details we refer to a recently published standard operating procedure [18]. In this review, we present an overview of the current understanding

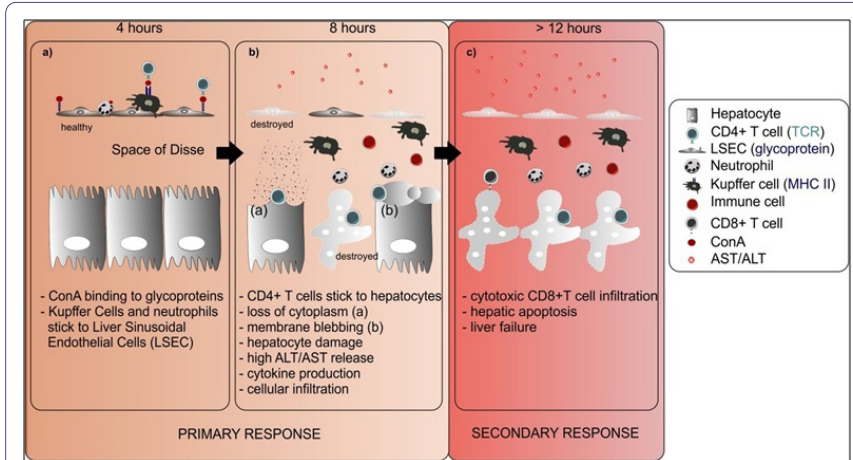

Figure 1: First model of Concanavalin A (ConA)-mediated liver damage as described in Tiegs et al. 1992 [17].

Entering the bloodstream, Concanavalin A (ConA) can bind mannose rich glycoproteins on Liver Sinusoidal Endothelial Cells (LSECs), Kupffer cells and neutrophils leading to the activation of CD4+ T cells. In a primary response, leukocytes such as Kupffer cells and neutrophils (4 hours) and CD4+ T cells ( 8 hours) are found sticking to the endothelium and hepatocytes respectively. At later timepoints ( $>12$ hours), secondary events are mediated by CD8+ cytotoxic $T$ cells leading to massive hepatocyte apoptosis and eventually liver failure. Upon liver damage, starting at 4 hours, alanine aminotransferase (ALT) and aspartate aminotransferase (AST) are released from the hepatocyte cytoplasm and their activity in the serum is increased over time.

of the cell types (Table 1) and molecules which are involved in ConA-induced liver injury. In addition, we will summarize successful therapeutic interventions and their effects on important factors and cell types in disease development.

\section{T Cells}

$\mathrm{T}$ cell activation has direct cytotoxic effects on hepatocytes in vitro [69] and is crucial in the development of liver damage caused by ConA stimulation in vivo [17]. The necessity of T cells for ConA-induced liver injury was documented by different groups using a variety of tools such as mice with Severe Combined Immunodeficiency Syndrome (SCID) lacking immunocompetent $\mathrm{T}$ and $\mathrm{B}$ cell [17], athymic nude mice with functionally defective immature T cells [17,70], RAG-1 deficient mice devoid of T and B cells $[19,71]$ and a Th1.2 antibody that depletes all antigen-bearing $\mathrm{T}$ cells [17]. More specifically, the induction of liver injury requires CD4+ $\mathrm{T}$ cells, not CD8+ T cells, because depletion of CD4+ T cells with a monoclonal antibody against CD4 glycoprotein but not against CD8 completely protected against ConA-induced liver injury [17,26,71]. However, depletion of CD4+ and CD8+ reduced liver injury to a greater extent than depleting only CD4+ T cells [26]. The dominant role of $\mathrm{CD} 4+\mathrm{T}$ cells in ConA hepatitis is no surprise knowing that, in early reports, administration of ConA to mice and rats led to the accumulation of CD4+ cells in the liver, but not CD8+ T cells $[72,73]$. Conversely, other reports did observe CD8+ T cells accumulation in the liver [74] and these cells were even the main producers of IFN- $\gamma$ [45]. Moreover, in vitro data show that ConA induces more proliferation of $\mathrm{CD} 8+\mathrm{T}$ cells than $\mathrm{CD} 4+\mathrm{T}$ cells [75]. These results indicate that ConA affects $\mathrm{CD} 8+\mathrm{T}$ cells but the cytotoxic role of $\mathrm{CD} 8+$ $\mathrm{T}$ cells is secondary to the role of CD4+ T cells [74].

ConA activates $\mathrm{T}$ cells to proliferate, produce cytokines and migrate to the liver [46]. Several adhesion molecules play an important role in accumulation of CD4+ $\mathrm{T}$ cells but not $\mathrm{CD} 8+\mathrm{T}$ cells [76]. By helping APCs and cytotoxic CD8+ T cells, CD4+ helper $\mathrm{T}$ cells are important in the initiation of an adaptive immune response. $\mathrm{CD} 4+\mathrm{T}$ cells are divided into four major subsets based on their secreted cytokines and expression profile of transcription factors, 
Citation: Ballegeer M, Libert C (2016) Different Cell Types Involved in Mediating Concanavalin A Induced Liver Injury: A Comprehensive Overview. J Gastroenterol Hepatology Res 1: 001 .

- Page 3 of $13 \cdot$

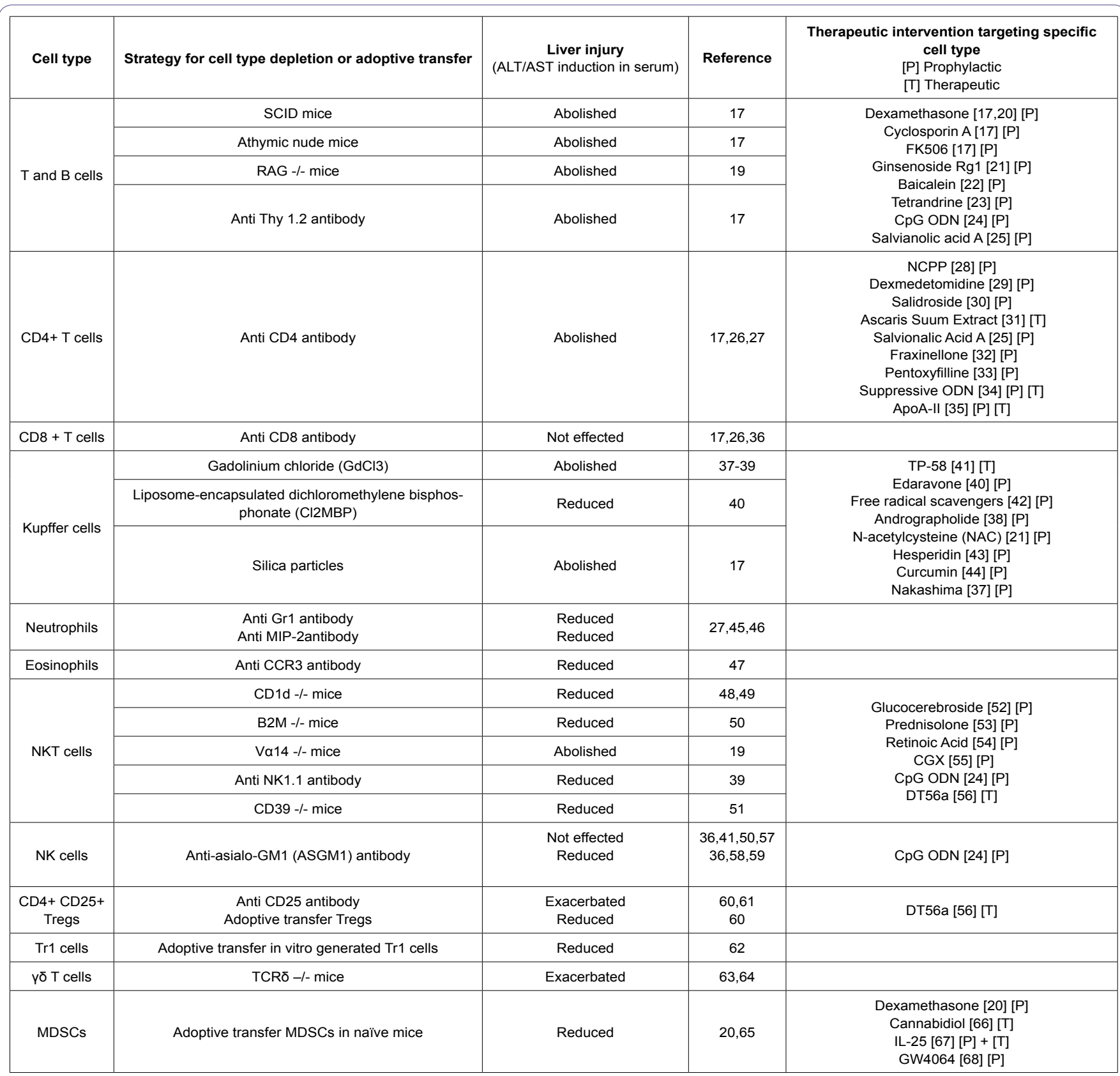

Table 1: Studies showing the importance of different cell types that are involved in ConA-mediated liver inflammation and therapeutic approaches used to manipulate them.

namely, Th1, Th2, Th17 and regulatory $\mathrm{T}$ cells (Tregs) [77]. The involvement of and interplay between these $\mathrm{T}$ cell subsets in ConA-induced liver injury will be discussed in the following sections and is summarized in Figure 2.

\section{Th1 cells}

The differentiation of Th 0 to Th1 cells is mainly induced by Interleukin (IL)-12 and can be further enhanced by IFN- $\gamma$ in a feedback loop, because next to TNF- $\alpha$ and IL-2, IFN- $\gamma$ is one of the major cytokines secreted by Th1 cells $[78,79]$. Several studies using recombinant IFN- $\gamma$, IFN- $\gamma$ antibodies and deficiency have shown that IFN- $\gamma$ plays a crucial role in the development of ConA-induced liver injury $[27,37,47,80-82]$. In the absence of IFN- $\gamma$, hepatocytes don't die by apoptosis and production of TNF- $\alpha$ by activated macrophages is reduced [79-81,83]. Another key Th1 associated cytokine is TNF- $\alpha$, which is also local and systemically strongly induced upon ConA administration [81]. However, the importance of this cytokine in the development of liver injury has been controversial. Initial reports demonstrate that neutralization of TNF- $\alpha$ was unable to prevent the development of ConA-induced hepatitis [17,81]. Using mice deficient in TNF Receptor (TNFR) 1 or TNFR2 deficient mice and TNF- $\alpha$ neutralizing antibodies, later studies reported protection against ConA-induced liver injury [37,47,84-86]. Interestingly, cooperative signaling between the two TNFRs is important for the induction of liver damage [80]. TNFR2 on the parenchyma but not on leukocytes can attract adaptor molecules such as TRAF2 which facilitates TNFR1 induced activation of the pro-apoptotic pathway of 
nuclear factor NF- $\mathrm{kB}[87,88]$. TNFR1, on the other hand, is necessary for NF- $\kappa B$ activation in immune cells [86].

IL-12 is produced mainly by monocytes, macrophages and Dendritic Cells (DCs) [89] and plays an important role in the production of Th1 cytokines as well as Th2 cytokines by activation of Signal Transducer and Activator of Transcription (STAT) $4[90,91]$. IL-12 is detrimental in ConA-induced liver injury model as its administration exacerbates the signs of ConA-induced hepatitis. Additionally, its neutralization ameliorates them by reducing the expression of Th1 and Th2 cytokines [82,92]. In contrast, recent results using IL12 and STAT4 deficient mice reveal a protective role of IL12 induced activation of STAT-4 via indirect or direct down regulation of FasL in Natural Killer T (NKT) cells. These conflicting results indicate that IL-12 and STAT4 may play a dual role in ConA-induced hepatitis by promoting cytokine production and inhibiting NKT cell function [93].

\section{Th2 cells}

Th2 cells produce mainly IL-4, IL- 5 and IL- 13 . Together with IL-4, the transcription factors STAT6 and GATA binding protein (GATA)3 drive Th0 cells towards Th2 commitment [94]. Using IL-4 specific antibodies, several groups showed that depleting IL-4 protects against ConA-induced liver injury $[51,82,95]$. Moreover, most of the interventions therapeutically or genetically reducing IL-4 levels lead to amelioration of ConA-induced injury.

\section{Th17 cells}

The combination of Transforming Growth Factor (TGF)- $\beta$, IL-6 and IL-21 is needed for the differentiation of Th17 cells, which are characterized by the production of IL-17, IL-21, IL-22 and TNF- $\alpha$ $[96,97]$. After triggering Th17 cell differentiation, the cells start to produce IL-21, which causes amplification by positive feedback and IL-23 receptor expression. Production of IL-23 and IL-21 induces the expression of RAR-related orphan receptor (ROR) $y \mathrm{t}$, which is necessary for the development of Th17 cells [98]. Development of Th17 is suppressed by IFN- $\gamma$ and IL-4, which commit Th 0 cells to Th 1 and Th2, respectively. Next to ROR $\gamma$ t, Th17 cells activate STAT3 and RORa transcription factors, leading to the production of IL22, IL-17 A and IL-17F [99]. IL-17 family members play important roles in local tissue inflammation and cause KCs to release pro-inflammatory cytokines such as IL- 6 and TNF- $\alpha$ but also influence neutrophil recruitment/activation and Th1/Th2 activation [100]. IL-17 is believed to be a marker of AIH severity. In the ConA model, increased expression of IL-17 was also observed in CD4+ T and NKT cells $[100,101]$. Moreover, IL-17 secretion by activated T cells upon ConA stimulation promoted TNF- $\alpha$ and IL- 6 production by KCs, causing liver damage [100]. Supporting this pro-inflammatory role of IL-17, neutralization or deficiency of IL-17 led to reduced ConA-induced liver damage whereas exogenous IL-17 aggravated it $[71,100,102,103]$. Nevertheless, the complete role of IL-17 in the pathogenesis of ConA-induced hepatitis remains unclear since an immunosuppressive role was recently described [104]. By promoting inducible Nitric Oxide Synthase (iNOS) expression in mesenchymal stem cells and induction of cytokine/chemokine gene expression, IL-17 can enhance in vivo immunosuppressive effects in ConA-induced hepatitis [103-106].

IL-22 is known to protect hepatocytes from the destructive effect of IFN- $\gamma$ produced by different immune cells [105]. IL-22 has no direct effect on immune cells but affects liver tissue by activating
STAT3 and Akt in hepatocytes, leading to the induction of anti-apoptotic and cell survival genes. The hepatoprotective role of IL-22 in ConA-induced injury was confirmed by treating IL-22 deficient mice [105]. It is important to note that Th17 cells are not the only source of IL-22, for example, Notch signaling in CD4+ T cells is crucial for IL-22 expression in a Th17 independent manner [107]. Interestingly, IL-22 seems to be pro-inflammatory in the presence of IL-17 but protective in its absence [108]. IL-23 does not initiate Th17 cell differentiation but acts as a survival cytokine maintaining Th17 responses. Th17 master regulators STAT3 and ROR $\gamma \mathrm{t}$ are essential for the expression of its receptor [109]. In ConA-induced hepatitis, the induction of IL-23 expression and Notch activation results in the production of IL-22 which is critical for protection. IL-23 induces the expression of IL-17 as well, which is detrimental in the pathogenesis, showing that IL-23 has both a hepatotoxic and a protective role [103].

As mentioned above, STAT3 is an important transcription factor involved in the induction of the Th17 specific cytokine profile. It has opposing roles in myeloid and $\mathrm{T}$ cells in ConA-induced hepatitis. In myeloid cells it inhibits STAT1 and NF- $\kappa \mathrm{B}$ activation; thereby inhibiting hepatitis by downregulating the production of various cytokines such as IL-6, IL-12 and IFN- $\gamma$. In T cells, it leads to the expression of Th17 specific inflammatory cytokines, including IL-17, which might play a detrimental role in ConA-induced liver injury [102].

\section{Regulatory T cells (Tregs)}

The main function of CD4 regulatory T cells (Tregs) is to suppress the activation and/or effector actions of immune cells such as DCs, T, B, NK and NKT cells. Tregs are divided into three subsets: CD4+ CD25+ Foxp3+ cells, Tr 1 cells and Th3 cells. Resident CD4+ CD25+ Tregs exert their suppressive function by direct cell contact via membrane bound molecules. This type of Tregs develops directly from CD4+ T cell precursors during positive selection. In contrast, induced $\operatorname{Tr} 1$ and Th 3 cells do not use contact but secrete IL-10 or TGF- $\beta$ and differentiate from naive conventional $\mathrm{CD} 4+\mathrm{T}$ cells $[110,111]$. In ConA-induced hepatitis, the absolute number of Foxp3 positive Tregs is significantly increased and CD4+ CD25+ Treg activities/functions are enhanced $[61,112]$. Tregs are attracted to the liver by LSECs and hepatocytes expressing $\mathrm{C}-\mathrm{X}-\mathrm{C}$ motif chemokine ligand (CXCL) 9/10/11 leading to attraction of C-X-C Receptor (CXCR)3 positive CD4+ T cells and Tregs $[113,114]$.

The inhibitory function of Tregs is mediated by TGF- $\beta$, which is needed to suppress the injury caused by effector $\mathrm{T}$ cells [61]. Depleting CD25+ cells aggravated ConA-induced injury, and treating mice with CD4+ CD25+ Tregs made them less susceptible; this illustrates the therapeutic potential of Tregs [62]. For example, galectin-9 plays an important role in inducing apoptosis of TIM-3 positive activated CD4+ T cells and is predominantly expressed on Tregs [115-117]. In ConA-induced hepatitis, TIM3 neutralization, which blocks the effects of the endogenous ligand of galectin-9, aggravates liver injury by inhibiting the suppressive activities of Tregs $[26,118]$. Moreover, administration of galectin-9 ameliorates injury by downregulating the number of CD4+ effector T cells and their infiltration and cytokine production in the liver [26]. This example shows that the number of Tregs is important in overcoming ConA-induced hepatitis and interfering with Treg amount either exacerbates or improves injury.

ConA also induces $\operatorname{Tr} 1$ cells which secrete IL-10 and are Foxp3 negative [63]. IL-10 produced by Tregs and KCs plays a prominent 
role in the induction of tolerance. Interestingly, one single sublethal dose of ConA can induce tolerance within eight days. This tolerogenic state is characterized by an anti-inflammatory cytokine profile, with IL-10 as one of the major cytokines [62]. Restoring self-tolerance could be a valid therapeutic strategy because deficiency of Treg number or function plays a key role in ConA induced hepatitis. For a detailed review on using regulatory $\mathrm{T}$ cells to treat liver disease we refer to [119]. However, the role of Tregs in the pathogenesis of $\mathrm{AIH}$ and other autoimmune diseases is not clear. Recent reports show that Treg frequency and function are not impaired in AIH but the liver infiltrating Tregs are not able to block disease progression [120].

\section{$\gamma \delta \mathrm{T}$ cells}

In humans, $95 \%$ of the $\mathrm{T}$ cells express a T Cell Receptor (TCR) consisting of $\alpha$ - and a $\beta$-chain ( $\alpha \beta$ T cells), whereas in $5 \%$ of T cells the TCR has both $\gamma$ - and $\delta$ - chains ( $\gamma \delta$ T cells). The features and functions of $\gamma \delta \mathrm{T}$ cells are distinct from those of $\alpha \beta \mathrm{T}$ cells, and $\gamma \delta \mathrm{T}$ cells recognize both non-self and self-antigens [121]. $\gamma \delta \mathrm{T}$ cells can be divided into two major subsets: antigen experienced $\gamma \delta$ T cell produce IFN- $\gamma$ whereas antigen naive $\gamma \delta \mathrm{T}$ cells produce IL-17 [122]. According to their TCR, peripheral $\gamma \delta$ T cells are divided into $\mathrm{V} \gamma 1 \gamma \delta$ $\mathrm{T}$ and $\mathrm{V} \gamma 4 \gamma \delta \mathrm{T}$ cells [123-125]. $\mathrm{V} \gamma 4 \gamma \delta \mathrm{T}$ cells are the main source of IL-17 in the periphery and play a protective role in ConA-induced hepatitis by negatively regulating IFN- $\gamma$ production by NKT cells [59]. In contrast, $\mathrm{V} \gamma 1 \gamma \delta \mathrm{T}$ cells were not protective, supporting the idea that these $\gamma \delta$ T cell subsets have divergent functions in some disease models [126].

\section{NKT Cells}

NKT cells are a special subset of lymphocytes that express both the TCR with the invariant VaJa-chain and NK cell associated markers, including NK1. 1. These cells are considered to form a bridge between the innate and the adaptive immune systems. NKT cells are enriched in the liver and constitute about $30 \%$ of hepatic lymphocytes [127]. There are two distinct subpopulations of NKT cells: type I (95\% of NKT cells) and type II (5\% of NKT cells) [128]. Type I invariant iNKT cells have a highly restricted TCR repertoire, in contrast to the type II non-invariant NKT cells, which express a wide range of TCRs $[129,130]$. The crucial role of NKT cells in the pathogenesis of ConA-induced hepatitis has been shown by different studies using NKT deficient mice, depleting antibodies or NOD mice partially iNKT deficient $[19,37,49,50,51,92,131]$. Although NKT cells are one of the predominant effector cells in ConA-induced liver injury, they are rapidly depleted from the liver by Fas/FasL mediated apoptosis [49].

Activation of NKT cells is mediated by presentation of lipid antigens by CD1d but needs additional signals from KCs, LSECs, Hepatic Stellate Cells (HSCs), Myeloid Derived Suppressor Cells (MDSCs) and hepatocytes [132]. One of the most important signals is IL-12, produced mainly by APCs, which acts on iNKT via the IL-12R and triggers increased production of IL-4 $[92,133]$. In ConA-induced hepatitis, NKT cells are required for IL- 4 induction which is essential for TNF- $\alpha$ production and liver damage [51]. Once they are activated, NKT cells release large amounts of Th1 cytokines (IFN- $\gamma$, TNF- $\alpha$ and IL-2) and Th2 cytokines (IL-4, IL-5, IL-10 and IL-13) [130]. NKT cells directly induce hepatocyte death through release of TNF- $\alpha$ or perforins/granzyme B and/or upregulation of FasL [134]. Next to this, upon TCR engagement iNKT cells can rapidly produce a mixture of cytokines involved in the differentiation of Th0 cell into Th1 or Th2 cells [135-137]. So by releasing of IFN- $\gamma$, NKT cells can indirectly induce hepatocyte death by driving a Th1 biased phenotype and converting CD8+ $\mathrm{T}$ lymphocytes into cytotoxic $\mathrm{T}$ lymphocytes (CTLs) (Figure2). It is clear that NKT cells play a well-established detrimental role in the course of ConA-induced injury. Hence, interfering with the development, recruitment or activation of NKT cells in the liver could be an effective therapeutic strategy.

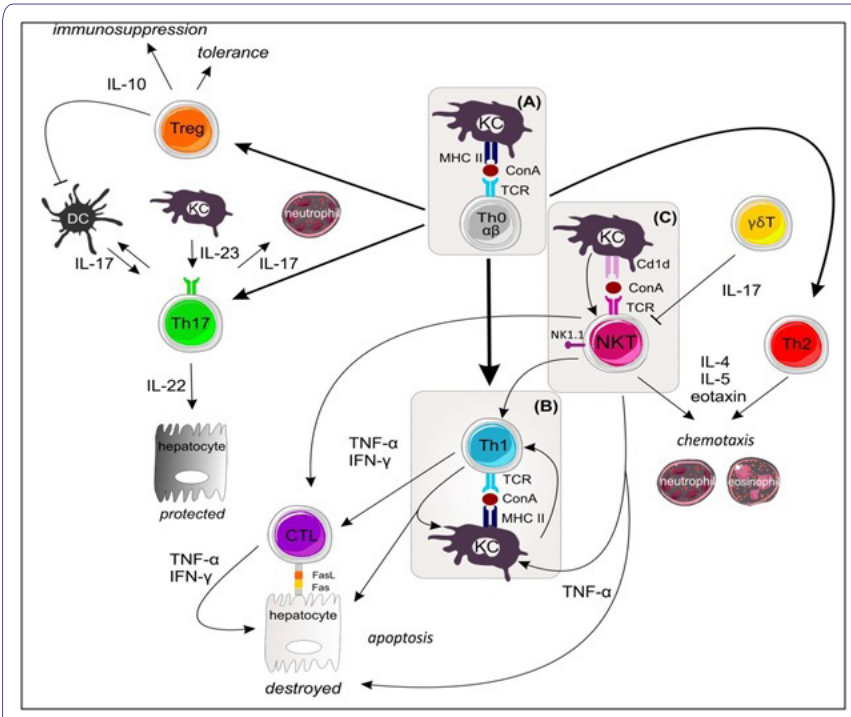

Figure 2: Interplay between different $T$ cell subsets and innate immune cells involved in ConA-mediated liver injury.

ConA is recognized by MHC $I$ (depicted in grey boxes A and B) and Cd1d molecules (grey box C) on Kupffer Cells (KCs) leading to the differentiation of CD4+ T cells and activation of Th1 and NKT cells respectively. Upon ConA stimulation, Th0 cells (grey) differentiate in Th1, Th2, Th17 and regulatory $\mathrm{T}$ cells (bold black arrows). Production of IL-4, IL-5 and eotaxin by Th2 (red) and NKT cells (pink) attracts neutrophils and eosinophils to the liver (chemotaxis). Additionally, activation of NKT cells but also Th1 cells (blue) promotes chemokine/cytokine production by $\mathrm{KCs}$ and cell death of hepatocytes via TNF- $\alpha$ and IFN-y production. Apoptosis of hepatocytes can be either directly or via CTLs or cytotoxic CD8 T lymphocytes (purple) and Fas/FasL activation. ConA also induces differentiation of Th17 cells (green) producing IL-17 which has hepatotoxic effects via stimulation of dendritic cells (DCs) and neutrophils and IL-22 which protects hepatocytes from destruction. As a protective mechanism, y $\delta \mathrm{T}$ cells (yellow) and Tregs (orange) are induced leading to NKT cell inhibition, immunosuppression and tolerance. ConA = Concanavalin $\mathrm{A}$; Th = T helper; $\mathrm{CTL}=$ Cytotoxic $\mathrm{T}$ Lymphocytes; $\mathrm{KC}=$ Kupffer Cell; NKT = Natural Killer T cell; $\mathrm{MHC}$ II = Major Histocompatibility Complex II; DC= Dendritic Cell; TCR $=$ T Cell Receptor; Cd1d = Cluster of Differentiation $1 \mathrm{~d}$; TNF- $\alpha=$ Tumor Necrosis Factor-alpha; IFN = Interferon- $\gamma$; $\mathrm{IL}=$ Interleukin; FasL = Fas Ligand.

\section{Hepatocytes}

Upon ConA challenge, IL-1 $\beta$ serum levels are increased, and this cytokine is a key mediator in the pathogenesis of the disease $[84,85]$. Hepatocytes are the major source of both circulating and hepatic IL-1Ra, which plays a critical role in the resolution of hepatic damage [138]. After ConA stimulation, TNF- $\alpha$ induces liver damage by activating both TNFR1 and TNFR2 $[80,139]$. However, TNF- $\alpha$ is not the only factor inducing apoptosis in the liver. Hepatocytes are very prone to Fas/FasL-mediated apoptosis because of their strong expression of Fas [140]. This type I integral membrane protein of the TNF receptor family transduces cell death signals and administration of a monoclonal agonistic Fas stimulating antibody leads to massive hepatocyte apoptosis and consequent liver damage [141-143]. However, the role of Fas/FasL in ConA-induced hepatitis remains controversial. Several studies have shown that blocking Fas/FasL signaling using antibodies, deficient mice or siRNA prevents 
ConA-induced liver injury $[81,134,144,145]$. In contrast, others researchers did not demonstrate a significant role for Fas/FasL but claimed that perforin-mediated cytotoxicity is important $[69,85,134,146]$. Interestingly, deficiency of caspase 1 , which is a common intermediate of TNF- $\alpha$ and FasL signaling, also leads to protection against ConA-induced hepatitis [85,147].

As mentioned above, IL-22 targets epithelial cells such as hepatocytes and plays an essential antihepatotoxic role in ConA-induced injury [105,148-150]. The protective role of IL-22 is mediated through activation of STAT3 and subsequent induction of the anti-apoptotic proteins Bcl2 and Bcl-xL $[148,149]$. Next to this, strong IL-33 expression in hepatocytes is controlled by NKT cell activation [50]. IL-33, a new member of the IL-1 family, reduces the severity of liver damage caused by ConA stimulation by recruiting regulatory $\mathrm{T}$ cells to the liver. The expression of IL-33 is dependent on TNF-Related Apoptosis-Inducing Ligand (TRAIL) but not on TNF- $\alpha$ and FasL [151]. TRAIL induces apoptosis by binding to death receptors, but it also initiates necroptosis $[152,153]$. TRAIL induces necroptosis by activating PARP-1 in a RIPK1/3 dependent manner, which leads to depletion of ATP and subsequently to programmed necrosis [154]. Since TRAIL is a crucial mediator of ConA-induced liver injury, this type of damage is driven not only by apoptosis but also by necroptosis [155]. Furthermore, elevated RIPK1 and RIPK3 expression indicate that necroptosis occurs during pathogenesis [156].

\section{Myeloid-Derived Suppressor Cells}

Myeloid Derived Suppressor Cells (MDSCs) expand during cancer, infection and inflammation, and have an outstanding ability to suppress $\mathrm{T}$ cell responses. This heterogeneous pool of myeloid cells has the morphology of granulocytes and monocytes [157]. Murine MDSCs are characterized by surface co-expression of Gr-1 and CD $11 \mathrm{~b}$ and are further subdivided into two major populations: $\mathrm{CD} 11 \mathrm{~b}+$ Ly6G+ Ly6C ${ }^{\text {low }}$ granulocytic MDSCs and CD11b+ Ly6G- Ly6C high $^{\text {hich }}$ monocytic MDSCs [158]. MDSCs use various mechanisms to influence both innate and adaptive immune responses. Most importantly, they deprive $\mathrm{T}$ cells of L-cysteine and L-arginine, generate oxidative stress, and can activate or expand Tregs (for a review on MDSC functions we refer to 159,160). To facilitate the suppression of T cell responses, MDSCs need iNOS, Arginase 1 and Reactive Oxygen Species (ROS) [161]. Recent findings suggest that the accumulation of MDSCs is linked to different types of inflammatory diseases such as inflammatory bowel disease [162] but also hepatitis $\mathrm{B}$ and $\mathrm{C}$ infections [66,163-165]. Moreover, in ConA-induced liver injury an expansion of MDSCs in the liver was observed and these cells suppressed the proliferation of an early $\mathrm{T}$ cell subset population [20].

Different therapeutic interventions have been shown to be associated with the induction and/or expansion of MDSCs during ConA-induced liver inflammation [20,66,67]. For example, treatment with glucocorticoids, which are strong anti-inflammatory molecules working through the GC receptor GR, led to accumulation of MDSCs and protected against liver injury $[20,166]$. A specific liver MDSC population with an unique surface marker expression profile was recently identified. Moreover, Zhu et al., demonstrated that only this population could inhibit CD4+ $\mathrm{T}$ cell responses and this inhibitory capacity depends on de novo expression of iNOS and subsequent $\mathrm{NO}$ production upon CD4+ T cell contact [65]. In human AIH patients, evidence for the presence of MDSCs is limited [167]. However, accumulation of CD11b + cells in liver biopsies has been reported [168]. Data on MDSC function in mouse models of AIH show that exhaustion of MDSCs and impairment of MDSC effector functions are part of the pathogenic mechanisms of the disease. Restoring the MDSC suppressive capacity or increasing the accumulation of MDSCs could thus be a promising therapeutic strategy for AIH. However, specific methods to generate these cells ex vivo so that they will be suitable for administration to patients will be challenging [159]. Especially because MDSCs are not terminally differentiated cells so depending on their surrounding milieu, they may mature into other myeloid cell types.

\section{Natural Killer Cells}

The cytotoxic and cytokine response of Natural Killer (NK) cells depends on their interaction with other cells of the immune system, such as T cells and NKT cells, as well on the cytokine environment [169]. In ConA-induced hepatitis, large numbers of NK cells are recruited from the bone marrow and spleen to the liver. Activation of NK cells requires other types of immune cells, such as NKT cells and $\mathrm{T}$ cells, and depends strongly on IFN- $\gamma$ production [58]. Since NK cells need other cells in order to perform their function, it could be expected that in vivo depletion of NK cells alone does not ameliorate ConA-induced liver injury $[36,51,58,170]$.

\section{Kupffer cells}

The liver resident macrophages or KCs constitute the first line of defense in the liver sinusoids that is in direct contact with all kinds of danger signals, such as microbial debris and gut derived pathogenic microbes. KCs phagocytose this exogenous material and degrade it, but they are also an important source of various inflammatory mediators. During disease, KCs interact with different neighboring cell types and the mediators they produce are central in influencing these cells. For a more detailed overview of the different cell-cell interactions and macrophage associated mediators in liver injury, we refer to Yang et al., [171].

Macrophages differentiate into M1 or M2 subsets, which are characterized by distinct markers and functions. The switch between pro-inflammatory M1 and anti-inflammatory M2 macrophages is controlled by mediators in the micro-environment of macrophages. A shift in the M1-M2 balance is correlated with the state of inflammation [171]. At the onset and during the first phase of acute hepatitis, macrophages exhibit a classical M1 phenotype and are hepatotoxic. In this phase, ConA activates KCs to produce large amounts of pro-inflammatory cytokines and promotes liver injury $[80,172]$. The essential role of KCs in disease development has been demonstrated by various research groups, who showed that KC depletion represses liver injury [38-40, 87]. Not surprisingly, depleting KCs does not affect the ability of ConA to induce the expression of important cytokines such as TNF- $\alpha$ and IFN- $\gamma$, suggesting that KCs are not the main producers of these factors. In contrast, the production and release of superoxide ROS is reduced after KC depletion; these species are critical in ConA-induced hepatitis $[37,39]$. In the second phase of hepatitis, macrophages display an M2-like phenotype, which is characterized by the production of anti-inflammatory and regenerative cytokines such as IL-10, TGF- $\beta$ and IL-6 [171]. M2 macrophages counteract the overwhelming pro-inflammatory events during the resolution phase of ConA-induced hepatitis [173]. The most important mediators involved in suppressing inflammation and promoting tissue repair have been reviewed by Yang et al., and will not be discussed further [171]. In a third phase, 
six hours after ConA challenge, the total number of KCs decreases but the remaining KCs have a more potent pro-inflammatory phenotype characterized by high IL-1 $\beta$ secretion [174]. As mentioned before, IL- $1 \beta$ is known as a critical pro-inflammatory cytokine during liver injury [175].

\section{Neutrophils}

Neutrophils are the first cell type to arrive at the site of inflammation in response to chemotactic factors. They migrate from the bloodstream to their target, where they attempt to resolve inflammation $[78,176,177]$. ConA challenge induces a recruitment of neutrophils to the liver within four hours. ConA can bind and activate neutrophils with consequent expression of adhesion molecules and release of reactive oxidants [179]. Accumulation of neutrophils is seen in the necrotic areas in the liver $[47,48]$. The activation and recruitment of neutrophils is a crucial step in the pathogenesis of ConA-induced liver inflammation $[45,46]$. Depleting neutrophils with an anti Gr1 antibody does not completely prevent but represses liver injury and leukocyte trafficking. Moreover, Bonder et al., showed that without neutrophils ConA cannot induce the recruitment of $\mathrm{T}$ cells and subsequent liver injury [46]. Activation of neutrophils leads to the expression of various mediators, such as IFN- $\gamma$, TNF- $\alpha$ and IL- 4 , which are known crucial factors in the development of ConA-induced liver injury, as discussed before [45].

\section{Eosinophils}

Eosinophils are important in mediating tissue damage through the release of toxic granule proteins, pro-inflammatory cytokines, chemokines and lipids. The activation of NKT cells in ConA-induced hepatitis results in a strong IL-4/STAT-6 dependent production of eotaxin and IL-5, leading to eosinophil and neutrophil infiltration into the liver [95]. IL-5 is not only responsible for the maturation, proliferation and differentiation of eosinophils but also, together with eotaxin, for the recruitment of eosinophils to the liver. The importance of eosinophils in ConA-induced liver inflammation was shown using the CCR3 antibody to deplete eosinophils. Treatment with this antibody and neutralization of IL-5 led to protection against ConA-induced injury [48]. Next to IL-5, Smad3 is an essential mediator of TGF- $\beta$ signaling and is important for the viability of eosinophils in vitro, supporting the idea that upon ConA stimulation, Smad3 promotes eosinophil function and survival $[180,181]$.

\section{Dendritic Cells}

In contrast to conventional DCs (CD11c+CD11b+ B220-) present in the spleen and other organs, hepatic DCs are thought to be plasmacytoid (CD11c+CD11b- B220+) [182]. Hepatic DCs are weak activators of immune responses and are believed to be more immunosuppressive and to have a somewhat immunotolerance phenotype $[183,184]$. During the early stages after ConA challenge (3-6h), the absolute number of DCs in the liver decreases, but during the later stages $(12-24 \mathrm{~h})$ their number increases again. Using adoptive transfers, Tomiyama et al., showed that only hepatic DCs could suppress the hepatic damage induced by ConA and this might be related to their ability to suppress IL-12 secretion and the subsequent Th1 response [184].

\section{Stromal Cells}

Stromal cells lining the hepatic sinusoids are the first cells to encounter gut-derived or systemic antigens. There are two major types, both of which can modulate the immune response: Liver Sinusoidal Endothelial Cells (LSECs) and Hepatic Stellate Cells (HSCs).

LSECs are the most abundant non parenchymal cell population in the liver. They are unique endothelial cells that line the hepatic sinusoids and define the space of disse. Although LSECs express low levels of MHC II and co-stimulatory molecules, they are scavengers that compete with DCs for the uptake of antigens circulating in the liver [185]. By physically interacting with DCs, LSECs can reduce the antigen presenting function of DCs [186]. After physical contact, DCs lose their ability to prime naive $\mathrm{T}$ cells due to reduced expression of co-stimulatory molecules. LSECS can also promote CD4+ T cell migration in a chemokine dependent way [187]. It was recently shown that the liver sinusoidal endothelium contains an intracellular transport system for chemokines to induce local recruitment of circulating T cells. During ConA-induced inflammation, LSECs internalize CXCL12 via CXCR4 mediated endocytosis, leading to enhanced CD4+ T cell migration [188]. LSECs can also reduce CD4+ $\mathrm{T}$ cell activity and promote the induction of Tregs using membrane bound TGF- $\beta[114,189,190]$.

HSCs are present in the perisinusoidal space between LSECs and hepatocytes. In normal conditions, HSCs (Ito cells) are important for Vitamin A storage and for regulation of blood flow in the sinusoids. In inflammatory conditions, HSCs form a second line of defense by limiting the effector function of $\mathrm{T}$ cells that have extravasated and thereby they prevent tissue damage. HSCs produce large amounts of anti-inflammatory mediators like IL-10 and TGF- $\beta$ [191]. By doing so, they can suppress DC function [192]. In addition, HSCs can induce NKT cell response by producing IL-15, present peptides to CD4 and CD8+ T cells, and induce T cell priming [193]. Next to LSECs, HSCs are the second APCs that reside in the liver. HSCs also facilitate the differentiation of inflammatory monocytes into MDSCs, which impair $\mathrm{T}$ cell function and proliferation [194]. Moreover, HSCs can induce and expand Tregs but the mechanism is not known [195,196]. For a full overview of hepatic immune regulation by stromal cells we refer to Schildberg et al., [197].

\section{Therapeutic Interventions}

Because of the great amount of cell types and mediators involved in the pathogenesis of the ConA induced liver inflammation; a lot of different therapeutic strategies have been tested in the last decades (depicted in the last column of Table 1). In most studies, strategies which inhibit $\mathrm{T}$ cell and macrophage activation leading to reduced cytokine production and liver damage are used. Known immunomodulatory agents like corticosteroids, cyclosporine A, paeoniflorin, glucocerebroside, curcumin and flavonoids -quercetin, hesperidin and baicalein- were able to reduce ConA associated cytokine production $[17,22,43,53,119,198,200]$. Unfortunately, most of the reported therapies are only effective when administered prophylactically (marked as [P] in Table 1) and some even lose their potential when used therapeutically (marked as [T] in Table 1). For example, pentoxyfilline, a strong suppressor of TNF- $\alpha$ release, is able to rescue the phenotype when administered prophylactically but the effect was lost when used therapeutically [33,201]. Luckily, there have been some studies identifying valid therapeutic strategies. For example, Y-40138 significantly suppressed the development of ConA-induced hepatitis by suppression of TNF- $\alpha$, MIP-2, IL-4 and IFN- $\gamma$ production [201]. Additionally, both quercetin and TP58, a novel thienopyridine derivative protect against liver injury by inhibiting NF- $\mathrm{kB}$ mediated inflammation $[41,198]$. Other strategies 
Citation: Ballegeer M, Libert C (2016) Different Cell Types Involved in Mediating Concanavalin A Induced Liver Injury: A Comprehensive Overview. J Gastroenterol Hepatology Res 1: 001 .

- Page 8 of $13 \cdot$

targeting regulatory $\mathrm{T}$ cells and/or NKT cell function have also been described. For example, oral administration of DT56a, a natural product isolated from soybeans, redistributed the CD4+ CD25+ $\mathrm{T}$ cells resulting in less liver damage [57]. New and interesting therapeutic opportunities arose when immunosuppressive MDSCs were shown to be induced upon ConA stimulation [20]. Later studies using dexamethasone show that its positive effect is specifically due to an increased MDSC induction [20]. Next to this, cannabidiol, a non-psychoactive cannabinoid and IL-25 treatment can reduce ConA induced inflammation and protect mice from liver injury by triggering the induction of MDSCs, opening a new window for therapeutic strategies [66,67].

\section{Conclusion}

The ConA model mimics important features of acute liver injury. The immune activation/infiltration and the involvement of T cells in this model make it particularly relevant to study acute liver injury. In this review we presented an overview of the different cell types and their mediators driving ConA-induced hepatitis. Decades of research have shown that the pathogenesis is more complex than anticipated by Tiegs et al., in 1992 (shown in figure 1) [17]. The great variety of immune cells, hepatocytes and stromal cells that play crucial roles in the development of the disease and the fact that different cell types influence the effector functions of their neighboring cells by producing different cytokines, chemokines and other effector molecules (shown in Figure 2) are responsible for this high complexity. It is now clear that ConA-induced hepatitis is the result of a well-orchestrated interaction network (Figure 3 ) and novel mediators are still being identified meaning that the full complexity of pathogenesis is not yet understood. Fortunately, successful therapeutic strategies targeting a specific mediator or cell type have been already identified. However, recent findings, like the induction of MDSCs, have great therapeutic potential but have not been investigated to a great extent and should be focused on in the future.

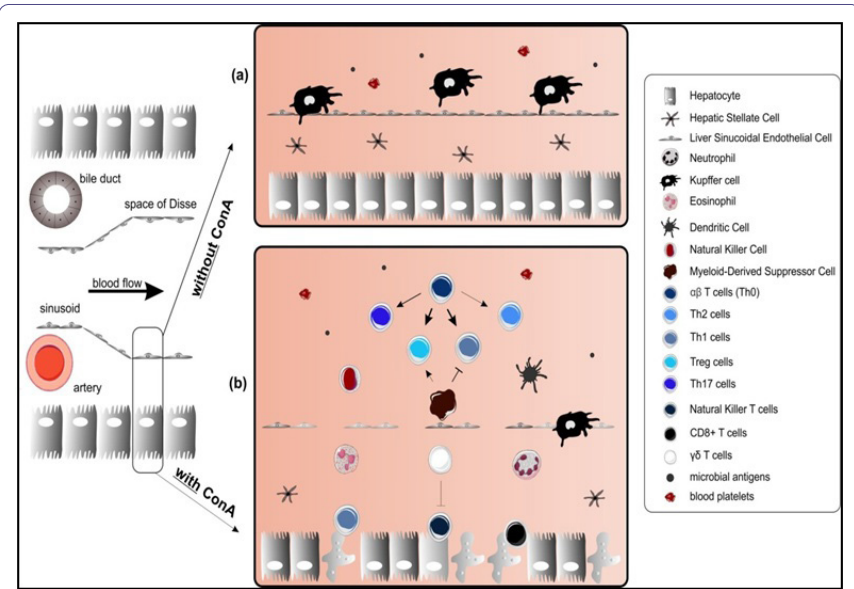

Figure 3: Updated model of Concanavalin A (ConA)-mediated liver damage response as a result of decades or research.

The architecture of sinusoids in the liver in the absence of presence of ConA is depicted.

(a) In normal conditions, oxygenated blood passes through the sinusoids containing blood platelets and microbial antigens. The area between the liver sinusoid endothelial cells (LSECs) and hepatocytes is called the space of Disse and contains stellate cells which control the blood flow. Immune cells reside in the sinusoids but are in close contact with the LSECs.

(b) After intravenous ConA injection, different immune cell types are recruited to the liver and infiltrate the parenchym causing inflammation and cell death resulting in liver failure.

\section{References}

1. Czaja AJ (2010) Animal models of autoimmune hepatitis. Expert Rev Gastroenterol Hepatol 4: 429-443.

2. Webb GJ, Hirschfield GM (2016) Using GWAS to identify genetic predisposition in hepatic autoimmunity. J Autoimmun 66: 25-39.

3. de Boer YS, van Gerven NM, Zwiers A, Verwer BJ, van Hoek B et al. (2015) Genome-wide association study identifies variants associated with autoimmune hepatitis type 1. Gastroenterology 147: 443-452.

4. Czaja AJ (2002) Autoimmune hepatitis after liver transplantation and other lessons of self-intolerance. Liver Transpl 8: 505-513.

5. Liberal R, Grant CR, Mieli-Vergani G, Vergani D (2013) Autoimmune hepatitis: a comprehensive review. J Autoimmun 41: 126-139.

6. Yüksel M, Laukens D, Heindryckx F, Van Vlierberghe $H$, Geerts A, et al. (2014) Hepatitis mouse models: from acute-to-chronic autoimmune hepatitis. Int J Exp Pathol 95: 309-320.

7. Czaja AJ (2009) Current and future treatments of autoimmune hepatitis. Expert Rev Gastroenterol Hepatol 3: 269-291.

8. Wang HX, Liu M, Weng SY, Li JJ, Xie C, et al. (2012) Immune mechanisms of Concanavalin A model of autoimmune hepatitis. World J Gastroenterol 18: $119-125$

9. Bonito AJ, Aloman C, Fiel MI, Danzl NM, Cha S, et al. (2013) Medullary thymic epithelial cell depletion leads to autoimmune hepatitis. J Clin Invest 123: 3510-3524.

10. Hintermann E, Ehser J, Christen UC (2012) The CYP2D6 animal model: how to induce autoimmune hepatitis in mice. J Vis Exp 3: 3644.

11. Bogdanos DP, Dalekos GN (2008) Enzymes as target antigens of liver-specific autoimmunity: the case of cytochromes P450s. Curr Med Chem 15: 2285-2292.

12. Christen U, Hintermann E (2015) An Update on Animal Models of Autoimmune Hepatitis: Are we There Yet? Curr Pharm Des 21: 2391-2400.

13. Jaeckel E, Hardtke-Wolenski M, Fischer K (2011) The benefit of animal models for autoimmune hepatitis. Best Pract Res Clin Gastroenterol 25: 643-651.

14. Soares PA, Nascimento CO, Porto TS, Correia MT, Porto AL, et al. (2011) Purification of a lectin from Canavalia ensiformis using PEG-citrate aqueous two-phase system. J Chromatogr B Analyt Technol Biomed Life Sci 879: 457-460.

15. Lis $\mathrm{H}$, Sharon $\mathrm{N}$ (1986) Biological properties of lectins. In: Liener JE, Sharon N, Goldstein IJ (eds.). The lectins: properties, functions and applications in biology and medicine. Acadamic Press, Inc, London. Pg no: 256-291.

16. Tiegs G, Hentschel J, Wendel A (1992) A T cell-dependent experimental liver injury in mice inducible by concanavalin A. J Clin Invest 90: 196-203.

17. Heymann F, Hamesch K, Weiskirchen R, Tacke F (2015) The concanavalin A model of acute hepatitis in mice. Lab Anim 49: 12-20.

18. Leist M, Wendel A (1996) A novel mechanism of murine hepatocyte death inducible by concanavalin A. J Hepatol 25: 948-959.

19. Kaneko Y, Harada M, Kawano T, Yamashita M, Shibata Y et al. (2000) Augmentation of Valpha14 NKT cell-mediated cytotoxicity by interleukin 4 in an autocrine mechanism resulting in the development of concanavalin A-induced hepatitis. J Exp Med 191: 105-114.

20. Diao W, Jin F, Wang B, Zhang CY, Chen J, et al. (2014) The protective role of myeloid-derived suppressor cells in concanavalin A-induced hepatic injury. Protein Cell 5: 714-724.

21. Cao L, Zou Y, Zhu J, Fan X, Li J (2013) Ginsenoside Rg1 attenuates concanavalin A-induced hepatitis in mice through inhibition of cytokine secretion and lymphocyte infiltration. Mol Cell Biochem 380: 203-210.

22. Zhang Y, Shan L, Hua Y, Wang D, Zeng H, et al. (2013) Baicalein selectively induces apoptosis in activated lymphocytes and ameliorates concanavalin a-induced hepatitis in mice. PLoS One 8: 69592. 
Citation: Ballegeer M, Libert C (2016) Different Cell Types Involved in Mediating Concanavalin A Induced Liver Injury: A Comprehensive Overview. J Gastroenterol Hepatology Res 1: 001.

23. Feng D, Mei Y, Wang Y, Zhang B, Wang C, et al. (2008) Tetrandrine protects mice from concanavalin A-induced hepatitis through inhibiting NF-kappaB activation. Immunol Lett 121: 127-133.

24. Zhang H, Gong Q, Li JH, Kong XL, Tian L, et al. (2010) CpG ODN pretreatment attenuates concanavalin A-induced hepatitis in mice. Int Immunopharmacol 10: 79-85.

25. Xu X, Hu Y, Zhai X, Lin M, Chen Z, et al. (2013) Salvianolic acid A preconditioning confers protection against concanavalin A-induced liver injury through SIRT1-mediated repression of p66shc in mice. Toxicol Appl Pharmacol 273: 68-76.

26. Lv K, Zhang Y, Zhang M, Zhong M, Suo Q (2012) Galectin-9 ameliorates Con A-induced hepatitis by inducing CD4(+)CD25(low/int) effector T-Cell apoptosis and increasing regulatory T cell number. PLoS One 7: 48379

27. Zhang S, Liang R, Luo W, Liu C, Wu X, et al. (2013) High susceptibility to liver injury in IL-27 p28 conditional knockout mice involves intrinsic interferon- $\gamma$ dysregulation of CD4+ T cells. Hepatology 57: 1620-1631.

28. Liu C, Gao S, Qu Z, Wang Q, Zhu F, et al. (2012) NCPP treatment alleviates ConA-induced hepatitis via reducing $\mathrm{CD} 4+\mathrm{T}$ activation and NO production. Immunopharmacol Immunotoxicol 34: 962-967.

29. Wang H, Hu B, Zou Y, Bo L, Wang J, et al. (2014) Dexmedetomidine premedication attenuates concanavalin A-induced hepatitis in mice. J Toxicol Sci 39: 755-764

30. Hu B, Zou Y, Liu S, Wang J, Zhu J, et al. (2014) Salidroside attenuates concanavalin A-induced hepatitis via modulating cytokines secretion and lymphocyte migration in mice. Mediators Inflamm 2014: 314081.

31. Nascimento WC, Silva RP, Fernandes ES, Silva MC, Holanda GC, et al (2014) Immunomodulation of liver injury by Ascaris suum extract in an experimental model of autoimmune hepatitis. Parasitol Res 113: 3309-3317.

32. Sun $Y$, Qin $Y$, Gong FY, Wu XF, Hua ZC, et al. (2009) Selective triggering of apoptosis of concanavalin A-activated $T$ cells by fraxinellone for the treatment of T-cell-dependent hepatitis in mice. Biochem Pharmacol 77: 17171724.

33. Shirin H, Bruck R, Aeed H, Frenkel D, Kenet G, et al. (1998) Pentoxifylline prevents concanavalin $\mathrm{A}$-induced hepatitis by reducing tumor necrosis factor alpha levels and inhibiting adhesion of $\mathrm{T}$ lymphocytes to extracellular matrix. J Hepatol 29: 60-67.

34. Li N, Liu Y, Li S, Fu C, Zhou R et al. (2015) Protective role of synthetic oligodeoxynucleotides expressing immunosuppressive TTAGGG motifs in concanavalin A-induced hepatitis. Immunol Lett 151: 54-60.

35. Yamashita J, Iwamura C, Sasaki T, Mitsumori K, Ohshima K, et al. (2011) Apolipoprotein A-II suppressed concanavalin A-induced hepatitis via the inhibition of CD4 T cell function. J Immunol 186: 3410-3420.

36. Li B, Sun R, Wei H, Gao B, Tian Z (2006) Interleukin-15 prevents concanavalin A-induced liver injury in mice via NKT cell-dependent mechanism. Hepatology 43: 1211-1219.

37. Nakashima H, Kinoshita M, Nakashima M, Habu Y, Shono S, et al. (2008) Superoxide produced by Kupffer cells is an essential effector in concanavalin A-induced hepatitis in mice. Hepatology 48: 1979-1988.

38. Okamoto T, Maeda O, Tsuzuike N, Hara K (1998) Effect of gadolinium chloride treatment on concanavalin A-induced cytokine mRNA expression in mouse liver. Jpn J Pharmacol 78: 101-103.

39. Shi G, Zhang Z, Zhang R, Zhang X, Lu Y, et al. (2012) Protective effect of andrographolide against concanavalin A-induced liver injury. Naunyn Schmiedebergs Arch Pharmacol 385: 69-79.

40. Hatano M, Sasaki S, Ohata S, Shiratsuchi Y, Yamazaki T, et al. (2008) Effects of Kupffer cell-depletion on Concanavalin A-induced hepatitis. Cell Immunol 251: 25-30.

41. Li Y, Wang ZL, He F, Wu Y, Huang W, et al. (2012) TP-58, a novel thienopyridine derivative, protects mice from concanavalinA-induced hepatitis by suppressing inflammation. Cell Physiol Biochem 29: 31-40.
42. Shirin $\mathrm{H}$, Aeed $\mathrm{H}$, Alin A, Matas Z, Kirchner M, et al. (2010) Inhibition of immune-mediated concanavalin a-induced liver damage by free-radical scavengers. Dig Dis Sci 55: 268-275.

43. Li G, Chen MJ, Wang C, Nie H, Huang WJ, et al. (2014) Protective effects of hesperidin on concanavalin A-induced hepatic injury in mice. Int Immunopharmacol 21: 406-411.

44. Tu CT, Han B, Yao QY, Zhang YA, Liu HC et al. (2012) Curcumin attenuates Concanavalin A-induced liver injury in mice by inhibition of Toll-like receptor (TLR) 2, TLR4 and TLR9 expression. Int Immunopharmacol 12: 151-157.

45. Hatada S, Ohta T, Shiratsuchi Y, Hatano M, Kobayashi Y (2005) A novel accessory role of neutrophils in concanavalin A-induced hepatitis. Cell Immunol 233: 23-29.

46. Bonder CS, Ajuebor MN, Zbytnuik LD, Kubes P, Swain MG (2004) Essential role for neutrophil recruitment to the liver in concanavalin A-induced hepatitis. J Immunol 172: 45-53.

47. Nakamura K, Okada M, Yoneda M, Takamoto S, Nakade Y, et al. (2001) Macrophage inflammatory protein-2 induced by TNF-alpha plays a pivotal role in concanavalin A-induced liver injury in mice. J Hepatol 35: 217-224.

48. Louis H, Le Moine A, Flamand V, Nagy N, Quertinmont E, et al. (2002) Critical role of interleukin 5 and eosinophils in concanavalin A-induced hepatitis in mice. Gastroenterology 122: 2001-2010.

49. Takeda K, Hayakawa Y, Kaer L, Matsuda H, Yagita H et al. (2000) Critical contribution of liver natural killer $\mathrm{T}$ cells to a murine model of hepatitis. Proc Natl Acad Sci USA 97: 5498-5503.

50. Arshad MI, Rauch M, L'Helgoualc'h A, Julia Vr, Leite-de-Moraes MC et al. (2011) NKT cells are required to induce high IL-33 expression in hepatocytes during ConA-induced acute hepatitis. Eur J Immunol 41: 2341-2348.

51. Toyabe S, Seki S, liai T, Takeda K, Shirai K, et al. (1997) Requirement of IL-4 and liver NK1 + T cells for concanavalin A-induced hepatic injury in mice. J Immunol 159: 1537-1542.

52. Beldi G, Wu Y, Banz Y, Nowak M, Miller L, et al. (2008) Natural killer T cell dysfunction in CD39-null mice protects against concanavalin A-induced hepatitis. Hepatology 48: 841-852.

53. Margalit M, Abu Gazala S, Ghazala SA, Alper R, Elinav E et al. (2005) Glucocerebroside treatment ameliorates ConA hepatitis by inhibition of NKT lymphocytes. Am J Physiol Gastrointest Liver Physiol 289: 17-25.

54. Kwon HJ, Won YS, Park O, Feng D, Gao B (2014) Opposing effects of prednisolone treatment on T/NKT cell- and hepatotoxin-mediated hepatitis in mice. Hepatology 59: 1094-1106.

55. Lee KA, Song YC, Kim GY, Choi G, Lee YS, et al. (2012) Retinoic acid alleviates Con A-induced hepatitis and differentially regulates effector production in NKT cells. Eur J Immunol 42: 1685-1694.

56. Shin JW, Wang JH, Kim HG, Park HJ, Bok HS, et al. (2010) CGX, a traditional Korean medicine ameliorates concanavalin A-induced acute liver injury. Food Chem Toxicol 48: 3308-3315.

57. Shabat Y, Lichtenstein Y, Zolotarov L, Ben Ya'acov A, Ilan Y (2013) Hepatoprotective effect of DT56a is associated with changes in natural killer T cells and regulatory T cells. J Dig Dis 14: 84-92.

58. Miyagi T, Takehara T, Tatsumi T, Suzuki T, Jinushi M et al. (2004) Concanavalin a injection activates intrahepatic innate immune cells to provoke an antitumor effect in murine liver. Hepatology 40: 1190-1196.

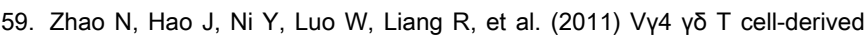
IL-17A negatively regulates NKT cell function in Con A-induced fulminant hepatitis. J Immunol 187: 5007-5014.

60. Beraza N, Malato Y, Sander LE, Al-Masaoudi M, Freimuth J, et al. (2009) Hepatocyte-specific NEMO deletion promotes NK/NKT cell- and TRAIL-dependent liver damage. J Exp Med 206: 1727-1737.

61. Wei HX, Chuang YH, Li B, Wei H, Sun R, et al. (2008) CD4+ CD25+ Foxp3+ regulatory $T$ cells protect against $T$ cell-mediated fulminant hepatitis in a TGF-beta-dependent manner in mice. J Immunol 181: 7221-7229. 
Citation: Ballegeer M, Libert C (2016) Different Cell Types Involved in Mediating Concanavalin A Induced Liver Injury: A Comprehensive Overview. J Gastroenterol Hepatology Res 1: 001.

62. Erhardt A, Biburger M, Papadopoulos T, Tiegs G (2007) IL-10, regulatory $T$ cells, and Kupffer cells mediate tolerance in concanavalin A-induced liver injury in mice. Hepatology 45: 475-485.

63. Ye F, Yan S, Xu L, Jiang Z, Liu N, et al. (2009) Tr1 regulatory T cells induced by ConA pretreatment prevent mice from ConA-induced hepatitis. Immunol Lett 122: 198-207.

64. Zhao N, Ni Y, Zhao L, Wu Z, Yin Z (2014) [Protective role of $y \delta$ T cells in concanavalin A-induced liver injury]. Zhonghua Gan Zang Bing Za Zhi 22: 58-62.

65. Li H, Dai F, Peng Q, Gan H, Zheng J, et al. (2015) Myeloid-derived suppressor cells suppress $\mathrm{CD} 4^{+}$and $\mathrm{CD} 8^{+} \mathrm{T}$ cell responses in autoimmune hepatitis. Mol Med Rep 12: 3667-3673.

66. Hegde VL, Nagarkatti PS, Nagarkatti M (2011) Role of myeloid-derived suppressor cells in amelioration of experimental autoimmune hepatitis following activation of TRPV1 receptors by cannabidiol. PLoS One 6: 18281.

67. Sarra M, Cupi ML, Bernardini R, Ronchetti G, Monteleone I, et al. (2013) IL25 prevents and cures fulminant hepatitis in mice through a myeloid-derived suppressor cell-dependent mechanism. Hepatology 58: 1436-1450.

68. Zhang H, Liu Y, Bian Z, Huang S, Han X, et al. (2014) The critical role of myeloid-derived suppressor cells and FXR activation in immune-mediated liver injury. J Autoimmun 53: 55-66.

69. Gossard AA, Lindor KD (2012) Autoimmune hepatitis: a review. J Gastroenterol 47: 498-503.

70. Gantner F, Leist M, Lohse AW, Germann PG, Tiegs G (1995) Concanavalin A-induced T-cell-mediated hepatic injury in mice: the role of tumor necrosis factor. Hepatology 21: 190-198.

71. Nagata T, McKinley L, Peschon JJ, Alcorn JF, Aujla SJ et al. (2008) Requirement of IL-17RA in Con A induced hepatitis and negative regulation of IL-17 production in mouse T cells. J Immunol 181: 7473-7479.

72. Mizuhara H, O'Neill E, Seki N, Ogawa T, Kusunoki C, et al. (1994) T cell activation-associated hepatic injury: mediation by tumor necrosis factors and protection by interleukin 6. J Exp Med 179: 1529-1537.

73. Tiegs $\mathrm{G}$ (2007) Cellular and cytokine-mediated mechanisms of inflammation and its modulation in immune-mediated liver injury. Z Gastroenterol 45: 6370 .

74. Bowen DG, Warren A, Davis T, Hoffmann MW, McCaughan GW, et al. (2002) Cytokine-dependent bystander hepatitis due to intrahepatic murine CD8 T-cell activation by bone marrow-derived cells. Gastroenterology 123 $1252-1264$

75. Azuma T, Watanabe N, Yagisawa H, Hirata H, Iwamura M, et al. (2000) Induction of apoptosis of activated murine splenic T cells by cycloprodigiosin hydrochloride, a novel immunosuppressant. Immunopharmacology 46: 2937.

76. Kawasuji A, Hasegawa M, Horikawa M, Fujita T, Matsushita Y, et al. (2006) L-selectin and intercellular adhesion molecule-1 regulate the development of Concanavalin A-induced liver injury. J Leukoc Biol 79: 696-705.

77. Hammerich L, Heymann F, Tacke F (2011) Role of IL-17 and Th17 cells in liver diseases. Clin Dev Immunol 2011: 345803.

78. O'Garra A, Arai N (2000) The molecular basis of T helper 1 and T helper 2 cell differentiation. Trends Cell Biol 10: 542-550.

79. Murphy KM, Reiner SL (2002) The lineage decisions of helper T cells. Nat Rev Immunol 2: 933-944.

80. Küsters S, Gantner F, Künstle G, Tiegs G (1996) Interferon gamma plays a critical role in $T$ cell-dependent liver injury in mice initiated by concanavalin A. Gastroenterology 111: 462-471.

81. Tagawa Y, Sekikawa K, Iwakura $Y$ (1997) Suppression of concanavalin A-induced hepatitis in IFN-gamma(-/-) mice, but not in TNF-alpha(-/-) mice: role for IFN-gamma in activating apoptosis of hepatocytes. J Immunol 159: 1418-1428.
82. Nicoletti F, Di Marco R, Zaccone P, Salvaggio A, Magro G et al. (2000) Murine concanavalin A-induced hepatitis is prevented by interleukin 12 (IL-12) antibody and exacerbated by exogenous IL-12 through an interferon-gamma-dependent mechanism. Hepatology 32: 728-733.

83. Glimcher LH, Murphy KM (2000) Lineage commitment in the immune system: the T helper lymphocyte grows up. Genes Dev 14: 1693-1711.

84. Mizuhara H, O'Neill E, Seki N, Ogawa T, Kusunoki C, et al. (1994) T cell activation-associated hepatic injury: mediation by tumor necrosis factors and protection by interleukin 6. J Exp Med 179: 1529-1537.

85. Ksontini R, Colagiovanni DB, Josephs MD, Edwards CK 3rd, Tannahill CL, et al. (1998) Disparate roles for TNF-alpha and Fas ligand in concanavalin A-induced hepatitis. J Immunol 160: 4082-4089.

86. Maeda S, Chang L, Li ZW, Luo JL, Leffert H, et al. (2003) IKKbeta is required for prevention of apoptosis mediated by cell-bound but not by circulating TNFalpha. Immunity 19: 725-737.

87. Fotin-Mleczek M, Henkler F, Samel D, Reichwein M, Hausser A, et al. (2002) Apoptotic crosstalk of TNF receptors: TNF-R2-induces depletion of TRAF2 and IAP proteins and accelerates TNF-R1-dependent activation of caspase-8. J Cell Sci 115: 2757-2770.

88. Schümann J, Prockl J, Kiemer AK, Vollmar AM, Bang R, et al. (2003) Silibinin protects mice from T cell-dependent liver injury. J Hepatol 39: 333-340.

89. Gee K, Guzzo C, Che Mat NF, Ma W, Kumar A (2009) The IL-12 family of cytokines in infection, inflammation and autoimmune disorders. Inflamm Allergy Drug Targets 8: 40-52.

90. Cho SS, Bacon CM, Sudarshan C, Rees RC, Finbloom D, et al. (1996) Activation of STAT4 by IL-12 and IFN-alpha: evidence for the involvement of ligand-induced tyrosine and serine phosphorylation. J Immunol 157: 47814789.

91. Morinobu A, Gadina M, Strober W, Visconti R, Fornace A, et al. (2002) STAT4 serine phosphorylation is critical for IL-12-induced IFN-gamma production but not for cell proliferation. Proc Natl Acad Sci USA 99: 1228112286.

92. Zhu R, Diem S, Araujo LM, Aumeunier A, Denizeau J, et al. (2007) The Pro-Th1 cytokine IL-12 enhances IL-4 production by invariant NKT cells: relevance for T cell-mediated hepatitis. J Immunol 178: 5435-5442.

93. Wang Y, Feng D, Wang H, Xu MJ, Park O, et al. (2014) STAT4 knockout mice are more susceptible to concanavalin A-induced T-cell hepatitis. Am J Pathol 184: 1785-1794

94. O'Garra A (2000) Commitment factors for T helper cells. Curr Biol 10: 492 494.

95. Jaruga B, Hong F, Sun R, Radaeva S, Gao B (2003) Crucial role of IL-4/ STAT6 in T cell-mediated hepatitis: up-regulating eotaxins and IL-5 and recruiting leukocytes. J Immunol 171: 3233-3244.

96. Veldhoen M, Hocking RJ, Atkins CJ, Locksley RM, Stockinger B (2006) TGFbeta in the context of an inflammatory cytokine milieu supports de novo differentiation of IL-17-producing T cells. Immunity 24: 179-189.

97. Wilson NJ, Boniface K, Chan JR, McKenzie BS, Blumenschein WM, et al. (2007) Development, cytokine profile and function of human interleukin 17-producing helper T cells. Nat Immunol 8: 950-957.

98. Ivanov II, McKenzie BS, Zhou L, Tadokoro CE, Lepelley A et al. (2006) The orphan nuclear receptor RORgammat directs the differentiation program of proinflammatory IL-17+ T helper cells. Cell 126: 1121-1133.

99. Lafdil F, Miller AM, Ki SH, Gao B (2010) Th17 cells and their associated cytokines in liver diseases. Cell Mol Immunol 7: 250-254.

100. Yan S, Wang L, Liu N, Wang Y, Chu Y (2012) Critical role of interleukin-17/ interleukin-17 receptor axis in mediating Con A-induced hepatitis. Immunol Cell Biol 90: 421-428.

101. Yasumi Y, Takikawa $Y$, Endo R, Suzuki K (2007) Interleukin-17 as a new marker of severity of acute hepatic injury. Hepatol Res 37: 248-254. 
Citation: Ballegeer M, Libert C (2016) Different Cell Types Involved in Mediating Concanavalin A Induced Liver Injury: A Comprehensive Overview. J Gastroenterol Hepatology Res 1: 001.

102. Lafdil F, Wang H, Park O, Zhang W, Moritoki Y, et al. (2009) Myeloid STAT3 inhibits T cell-mediated hepatitis by regulating T helper 1 cytokine and interleukin-17 production. Gastroenterology 137: 2125-2135.

103.Xu M, Morishima N, Mizoguchi I, Chiba Y, Fujita K, et al. (2011) Regulation of the development of acute hepatitis by IL-23 through IL-22 and IL-17 production. Eur J Immunol 41: 2828-2839.

104. Han X, Yang Q, Lin L, Xu C, Zheng C, et al. (2014) Interleukin-17 enhances immunosuppression by mesenchymal stem cells. Cell Death Differ 21 : 1758-1768.

105.Zenewicz LA, Yancopoulos GD, Valenzuela DM, Murphy AJ, Karow M, et al. (2007) Interleukin-22 but not interleukin-17 provides protection to hepatocytes during acute liver inflammation. Immunity 27: 647-659.

106. Hartupee J, Liu C, Novotny M, Li X, Hamilton T (2007) IL-17 enhances chemokine gene expression through mRNA stabilization. J Immunol 179: 4135-4141.

107.Alam MS, Maekawa Y, Kitamura A, Tanigaki K, Yoshimoto T, et al. (2010) Notch signaling drives IL-22 secretion in CD4+ T cells by stimulating the aryl hydrocarbon receptor. Proc Natl Acad Sci USA 107: 5943-5948.

108. Sonnenberg GF, Nair MG, Kirn TJ, Zaph C, Fouser LA, et al. (2010) Pathological versus protective functions of IL-22 in airway inflammation are regulated by IL-17A. J Exp Med 207: 1293-1305

109.Zhu J, Yamane H, Paul WE (2010) Differentiation of effector CD4 T cell populations (*). Annu Rev Immunol 28: 445-489.

110. Jonuleit H, Schmitt E, Stassen M, Tuettenberg A, Knop J et al. (2001) Identification and functional characterization of human CD4(+)CD25(+) T cells with regulatory properties isolated from peripheral blood. J Exp Med 193: 1285-1294.

111. Jonuleit $H$, Schmitt $E$ (2003) The regulatory T cell family: distinct subsets and their interrelations. J Immunol 171: 6323-6327.

112. Hu YP, Li XJ, Liu SW (2010) [Effects of ConA on early activation and function of CD4+ CD25+ Treg cells in mice]. Xi Bao Yu Fen Zi Mian Yi Xue Za Zhi 26: 118-120, 124.

113. Erhardt A, Wegscheid C, Claass B, Carambia A, Herkel J et al. (2011) CXCR3 deficiency exacerbates liver disease and abrogates tolerance in a mouse model of immune-mediated hepatitis. J Immunol 186: 5284-5293.

114.Carambia A, Freund B, Schwinge D, Heine M, Laschtowitz A, et al. (2014) TGF- $\beta$-dependent induction of $\mathrm{CD} 4^{+} \mathrm{CD} 25^{+}$Foxp $3^{+}$Tregs by liver sinusoidal endothelial cells. J Hepatol 61: 594-599.

115. Kashio Y, Nakamura K, Abedin MJ, Seki M, Nishi N, et al. (2003) Galectin-9 induces apoptosis through the calcium-calpain-caspase-1 pathway. J Immunol 170: 3631-3636.

116. Boenisch O, D'Addio F, Watanabe T, Elyaman W, Magee CN, et al. (2010) TIM-3: a novel regulatory molecule of alloimmune activation. J Immunol 185 5806-5819.

117.Ju Y, Shang X, Liu Z, Zhang J, Li Y et al. (2014) The Tim-3/galectin-9 pathway involves in the homeostasis of hepatic Tregs in a mouse model of concanavalin A-induced hepatitis. Mol Immunol 58: 85-91.

118. Wang F, Wan L, Zhang C, Zheng X, Li J, et al. (2009) Tim-3-Galectin-9 pathway involves the suppression induced by CD4+CD25+ regulatory $T$ cells. Immunobiology 214: 342-349.

119. Oo YH, Sakaguchi S (2013) Regulatory T-cell directed therapies in liver diseases. J Hepatol 59: 1127-1134.

120.Peiseler M, Sebode M, Franke B, Wortmann F, Schwinge D, et al. (2012) FOXP3+ regulatory $T$ cells in autoimmune hepatitis are fully functional and not reduced in frequency. J Hepatol 57: 125-132.

121.Carding SR, Egan PJ (2002) Gammadelta T cells: functional plasticity and heterogeneity. Nat Rev Immunol 2: 336-345.
122. Jensen KD, Su X, Shin S, Li L, Youssef S, et al. (2008) Thymic selection determines gammadelta $T$ cell effector fate: antigen-naive cells make interleukin-17 and antigen-experienced cells make interferon gamma. Immunity 29: $90-100$.

123. Heilig JS, Tonegawa S (1986) Diversity of murine gamma genes and expression in fetal and adult T lymphocytes. Nature 322: 836-840.

124. Ito K, Bonneville M, Takagaki Y, Nakanishi N, Kanagawa O, et al. (1989) Different gamma delta T-cell receptors are expressed on thymocytes at different stages of development. Proc Natl Acad Sci U S A 86: 631-635.

125. Pereira P, Gerber D, Huang SY, Tonegawa S (1995) Ontogenic development and tissue distribution of $\mathrm{V}$ gamma 1-expressing gamma/delta $\mathrm{T}$ lymphocytes in normal mice. J Exp Med 182: 1921-1930.

126. Born WK, Yin Z, Hahn YS, Sun D, O'Brien RL (2010) Analysis of gamma delta $T$ cell functions in the mouse. J Immunol 184: 4055-4061.

127. Swain MG (2008) Hepatic NKT cells: friend or foe? Clin Sci (Lond) 114: 457466.

128. Seino K, Taniguchi M (2005) Functionally distinct NKT cell subsets and subtypes. J Exp Med 202: 1623-1626.

129.Godfrey DI, MacDonald HR, Kronenberg M, Smyth MJ, Van Kaer L (2004) NKT cells: what's in a name? Nat Rev Immunol 4: 231-237.

130.Van Kaer L (2007) NKT cells: T lymphocytes with innate effector functions Curr Opin Immunol 19: 354-364.

131.Diao H, Kon S, Iwabuchi K, Kimura C, Morimoto J, et al. (2004) Osteopontin as a mediator of NKT cell function in T cell-mediated liver diseases. Immunity 21: $539-550$

132. Mattner J (2013) Natural killer T (NKT) cells in autoimmune hepatitis. Curr Opin Immunol 25: 697-703.

133. Habu Y, Uchida T, Inui T, Nakashima H, Fukasawa M, et al. (2004) Enhancement of the synthetic ligand-mediated function of liver NK1.1Ag+ T cells in mice by interleukin-12 pretreatment. Immunology 113: 35-43.

134. Seino K, Kayagaki N, Takeda K, Fukao K, Okumura K, et al. (1997) Contribution of Fas ligand to T cell-mediated hepatic injury in mice. Gastroenterology 113: $1315-1322$

135. Taniguchi M, Harada M, Kojo S, Nakayama T, Wakao H (2003) The regulatory role of Valpha14 NKT cells in innate and acquired immune response. Annu Rev Immunol 21: 483-513.

136. Brigl M, Brenner MB (2004) CD1: antigen presentation and T cell function. Annu Rev Immunol 22: 817-890.

137. Kronenberg M (2005) Toward an understanding of NKT cell biology: progress and paradoxes. Annu Rev Immunol 23: 877-900.

138. Lamacchia C, Rodriguez E, Palmer G, Vesin C, Seemayer CA, et al. (2012) Mice deficient in hepatocyte-specific IL-1Ra show delayed resolution of concanavalin A-induced hepatitis. Eur J Immunol 42: 1294-1303.

139. Wolf D, Hallmann R, Sass G, Sixt M, KÃ¹/4sters S et al. (2001) TNF-alpha-induced expression of adhesion molecules in the liver is under the control of TNFR1-relevance for concanavalin A-induced hepatitis. J Immunol 166: 1300-1307.

140.Kondo T, Suda T, Fukuyama H, Adachi M, Nagata S (1997) Essential roles of the Fas ligand in the development of hepatitis. Nat Med 3: 409-413.

141. Yonehara S, Ishii A, Yonehara M (1989) A cell-killing monoclonal antibody (anti-Fas) to a cell surface antigen co-downregulated with the receptor of tumor necrosis factor. J Exp Med 169: 1747-1756.

142. Itoh N, Yonehara S, Ishii A, Yonehara M, Mizushima S, et al. (1991) The polypeptide encoded by the cDNA for human cell surface antigen Fas can mediate apoptosis. Cell 66: 233-243.

143. Ogasawara J, Watanabe-Fukunaga R, Adachi M, Matsuzawa A, Kasugai T, et al. (1993) Lethal effect of the anti-Fas antibody in mice. Nature 364: 806-809. 
Citation: Ballegeer M, Libert C (2016) Different Cell Types Involved in Mediating Concanavalin A Induced Liver Injury: A Comprehensive Overview. J Gastroenterol Hepatology Res 1: 001.

144.Solorzano CC, Ksontini R, Pruitt JH, Hess PJ, Edwards PD, et al. (1997) Involvement of $26-k D a$ cell-associated TNF-alpha in experimental hepatitis and exacerbation of liver injury with a matrix metalloproteinase inhibitor. $J$ Immunol 158: 414-419.

145.Song E, Lee SK, Wang J, Ince N, Ouyang N, et al. (2003) RNA interference targeting Fas protects mice from fulminant hepatitis. Nat Med 9: 347-351.

146. Watanabe Y, Morita M, Akaike T (1996) Concanavalin A induces perforin-mediated but not Fas-mediated hepatic injury. Hepatology 24: 702-710.

147. Rodriguez I, Matsuura K, Ody C, Nagata S, Vassalli P (1996) Systemic injection of a tripeptide inhibits the intracellular activation of CPP32-like proteases in vivo and fully protects mice against Fas-mediated fulminant liver destruction and death. J Exp Med 184: 2067-2072.

148. Radaeva S, Sun R, Pan HN, Hong F, Gao B (2004) Interleukin 22 (IL-22) plays a protective role in T cell-mediated murine hepatitis: IL-22 is a survival factor for hepatocytes via STAT3 activation. Hepatology 39: 1332-1342.

149. Pan H, Hong F, Radaeva S, Gao B (2004) Hydrodynamic gene delivery of interleukin-22 protects the mouse liver from concanavalin A-, carbon tetrachloride-, and Fas ligand-induced injury via activation of STAT3. Cell Mol Immunol 1: 43-49.

150. Park O, Wang H, Weng $H$, Feigenbaum L, Li H et al. (2011) In vivo consequences of liver-specific interleukin-22 expression in mice: Implications for human liver disease progression. Hepatology 54: 252-261.

151. Volarevic V, Mitrovic M, Milovanovic M, Zelen I, Nikolic I, et al. (2012) Protective role of IL-33/ST2 axis in Con A-induced hepatitis. J Hepatol 56: 26-33.

152.Wu GS, Burns TF, Zhan Y, Alnemri ES, El-Deiry WS (1999) Molecular cloning and functional analysis of the mouse homologue of the KILLER/DR5 tumor necrosis factor-related apoptosis-inducing ligand (TRAIL) death receptor. Cancer Res 59: 2770-2775.

153. Meurette O, Rebillard A, Huc L, Le Moigne G, Merino D, et al. (2007) TRAIL induces receptor-interacting protein 1-dependent and caspase-dependent necrosis-like cell death under acidic extracellular conditions. Cancer Res 67 : 218-226.

154.Jouan-Lanhouet S, Arshad MI, Piquet-Pellorce C, Martin-Chouly C, Le Moigne-Muller G, et al. (2012) TRAIL induces necroptosis involving RIPK1/ RIPK3-dependent PARP-1 activation. Cell Death Differ 19: 2003-2014.

155.Zheng SJ, Wang P, Tsabary G, Chen YH (2004) Critical roles of TRAIL in hepatic cell death and hepatic inflammation. J Clin Invest 113: 58-64.

156. Deutsch M, Graffeo CS, Rokosh R, Pansari M, Ochi A, et al. (2015) Divergent effects of RIP1 or RIP3 blockade in murine models of acute liver injury. Cell Death Dis 6: 1759.

157. Youn JI, Nagaraj S, Collazo M, Gabrilovich DI (2008) Subsets of myeloid-derived suppressor cells in tumor-bearing mice. J Immunol 181: 5791-5802.

158. Kusmartsev S, Nefedova Y, Yoder D, Gabrilovich DI (2004) Antigen-specific inhibition of CD8+ $\mathrm{T}$ cell response by immature myeloid cells in cancer is mediated by reactive oxygen species. J Immunol 172: 989-999.

159. Gabrilovich DI, Nagaraj S (2009) Myeloid-derived suppressor cells as regulators of the immune system. Nat Rev Immunol 9: 162-174.

160. Nagaraj S, Gabrilovich DI (2012) Regulation of suppressive function of myeloid-derived suppressor cells by CD4+ T cells. Semin Cancer Biol 22: 282 288.

161.Ostrand-Rosenberg S, Sinha P (2009) Myeloid-derived suppressor cells: linking inflammation and cancer. J Immunol 182: 4499-4506.

162.Zhang J, Wang B, Zhang W, Wei Y, Bian Z, et al. (2013) Protein tyrosine phosphatase $1 \mathrm{~B}$ deficiency ameliorates murine experimental colitis via the expansion of myeloid-derived suppressor cells. PLoS One 8: 70828.

163. Chen S, Akbar SM, Abe M, Hiasa Y, Onji M (2011) Immunosuppressive functions of hepatic myeloid-derived suppressor cells of normal mice and in a murine model of chronic hepatitis B virus. Clin Exp Immunol 166: 134-142.
164. Tacke RS, Lee HC, Goh C, Courtney J, Polyak SJ, et al. (2012) Myeloid suppressor cells induced by hepatitis $C$ virus suppress $\mathrm{T}$-cell responses through the production of reactive oxygen species. Hepatology 55: 343-353.

165. Cai W, Qin A, Guo P, Yan D, Hu F, et al. (2013) Clinical significance and functional studies of myeloid-derived suppressor cells in chronic hepatitis $\mathrm{C}$ patients. J Clin Immunol 33: 798-808.

166. Varga G, Ehrchen J, Tsianakas A, Tenbrock K, Rattenholl A, et al. (2008) Glucocorticoids induce an activated, anti-inflammatory monocyte subset in mice that resembles myeloid-derived suppressor cells. J Leukoc Biol 84: 644-650.

167. Li H, Dai F, Peng Q, Gan H, Zheng J, et al. (2015) Myeloid-derived suppressor cells suppress $\mathrm{CD} 4^{+}$and $\mathrm{CD} 8^{+} \mathrm{T}$ cell responses in autoimmune hepatitis. Mol Med Rep 12: 3667-3673.

168. Senaldi G, Portmann B, Mowat AP, Mieli-Vergani G, Vergani D (1992) Immunohistochemical features of the portal tract mononuclear cell infiltrate in chronic aggressive hepatitis. Arch Dis Child 67: 1447-1453.

169.Long EO (2007) Ready for prime time: NK cell priming by dendritic cells. Immunity 26: 385-387.

170.Siebler J, Wirtz S, Frenzel C, Schuchmann M, Lohse AW, et al. (2008) Cutting edge: a key pathogenic role of IL-27 in T cell- mediated hepatitis. J Immunol 180: 30-33.

171. Yang Q, Shi Y, He J, Chen Z (2012) The evolving story of macrophages in acute liver failure. Immunol Lett 147: 1-9.

172. Künstle G, Hentze H, Germann PG, Tiegs G, Meergans T et al. (1999) Concanavalin $\mathrm{A}$ hepatotoxicity in mice: tumor necrosis factor-mediated organ failure independent of caspase-3-like protease activation. Hepatology 30 : 1241-1251.

173.Antoniades CG, Quaglia A, Taams LS, Mitry RR, Hussain M, et al. (2012) Source and characterization of hepatic macrophages in acetaminophen-induced acute liver failure in humans. Hepatology 56: 735-746.

174. Yang F, Lou G, Zhou X, Zheng M, He J et al. (2014) MicroRNA-223 acts as an important regulator to Kupffer cells activation at the early stage of Con A-induced acute liver failure via AIM2 signaling pathway. Cell Physiol Biochem 34: 2137-2152.

175.Imamura M, Tsutsui H, Yasuda K, Uchiyama R, Yumikura-Futatsugi S, et al. (2009) Contribution of TIR domain-containing adapter inducing IFN-beta-mediated IL-18 release to LPS-induced liver injury in mice. J Hepatol 51: 333-341.

176. Gerrard TL, Cohen DJ, Kaplan AM (1981) Human neutrophil-mediated cytotoxicity to tumor cells. J Natl Cancer Inst 66: 483-488.

177.van Kessel KP, van Strijp JA, Verhoef J (1991) Inactivation of recombinant human tumor necrosis factor-alpha by proteolytic enzymes released from stimulated human neutrophils. J Immunol 147: 3862-3868.

178. Niu XF, Smith CW, Kubes P (1994) Intracellular oxidative stress induced by nitric oxide synthesis inhibition increases endothelial cell adhesion to neutrophils. Circ Res 74: 1133-1140.

179. Weinbaum DL, Sullivan JA, Mandell GL (1980) Receptors for concanavalin A cluster at the front of polarized neutrophils. Nature 286: 725-727.

180. Yang YC, Piek E, Zavadil J, Liang D, Xie D, et al. (2003) Hierarchical model of gene regulation by transforming growth factor beta. Proc Natl Acad Sci USA 100: 10269-10274.

181. Kanzaki M, Shibagaki N, Hatsushika K, Mitsui H, Inozume T, et al. (2007) Human eosinophils have an intact Smad signaling pathway leading to a major transforming growth factor-beta target gene expression. Int Arch Allergy Immunol 142: 309-317.

182.Jomantaite I, Dikopoulos N, Kröger A, Leithäuser F, Hauser H, et al. (2004) Hepatic dendritic cell subsets in the mouse. Eur J Immunol 34: 355-365.

183. Pillarisetty VG, Shah AB, Miller G, Bleier JI, DeMatteo RP (2004) Liver dendritic cells are less immunogenic than spleen dendritic cells because of differences in subtype composition. J Immunol 172: 1009-1017. 
Citation: Ballegeer M, Libert C (2016) Different Cell Types Involved in Mediating Concanavalin A Induced Liver Injury: A Comprehensive Overview. J Gastroenterol Hepatology Res 1: 001.

184. Tomiyama C, Watanabe H, Izutsu Y, Watanabe M, Abo T (2011) Suppressive role of hepatic dendritic cells in concanavalin A-induced hepatitis. Clin Exp Immunol 166: 258-268.

185.Schurich A, Böttcher JP, Burgdorf S, Penzler P, Hegenbarth S, et al. (2009) Distinct kinetics and dynamics of cross-presentation in liver sinusoidal endothelial cells compared to dendritic cells. Hepatology 50: 909-919.

186. Schildberg FA, Hegenbarth SI, Schumak B, Scholz K, Limmer A, et al. (2008) Liver sinusoidal endothelial cells veto CD8 T cell activation by antigen-presenting dendritic cells. Eur J Immunol 38: 957-967.

187.Schrage A, Wechsung K, Neumann K, Schumann M, Schulzke JD, et al. (2008) Enhanced T cell transmigration across the murine liver sinusoidal endothelium is mediated by transcytosis and surface presentation of chemokines. Hepatology 48: 1262-1272.

188. Neumann K, Erben U, Kruse N, Wechsung K, Schumann M, et al. (2015) Chemokine Transfer by Liver Sinusoidal Endothelial Cells Contributes to the Recruitment of CD4+ T Cells into the Murine Liver. PLoS One 10: 0123867.

189.Knolle PA, Gerken G, Loser E, Dienes HP, Gantner F, et al. (1996) Role of sinusoidal endothelial cells of the liver in concanavalin A-induced hepatic injury in mice. Hepatology 24: 824-829.

190.Carambia A, Frenzel C, Bruns OT, Schwinge D, Reimer R, et al. (2013) Inhibition of inflammatory CD4 T cell activity by murine liver sinusoidal endothelial cells. J Hepatol 58: 112-118.

191.Schwabe RF, Seki E, Brenner DA (2006) Toll-like receptor signaling in the liver. Gastroenterology 130: 1886-1900.

192.Lee WC, Yu MC, Chiang YJ, Wang HC, Lu L et al. (2005) Liver stellate cells suppress dendritic cells through IL-10. Transplant Proc 37: 10-11.
193. Winau F, Hegasy G, Weiskirchen R, Weber S, Cassan C, et al. (2007) Ito cells are liver-resident antigen-presenting cells for activating $T$ cell responses. Immunity 26: 117-129.

194. Chou HS, Hsieh CC, Yang HR, Wang L, Arakawa Y, et al. (2011) Hepatic stellate cells regulate immune response by way of induction of myeloid suppressor cells in mice. Hepatology 53: 1007-1019.

195. Ichikawa S, Mucida D, Tyznik AJ, Kronenberg M, Cheroutre H (2011) Hepatic stellate cells function as regulatory bystanders. J Immunol 186: 5549-5555.

196.Dunham RM, Thapa M, Velazquez VM, Elrod EJ, Denning TL, et al. (2013) Hepatic stellate cells preferentially induce Foxp3+ regulatory $T$ cells by production of retinoic acid. J Immunol 190: 2009-2016.

197.Schildberg FA, Sharpe AH, Turley SJ (2015) Hepatic immune regulation by stromal cells. Curr Opin Immunol 32: 1-6.

198.Li X, Liu HC, Yao QY (2016) Quercetin Protects Mice from ConA-Induced Hepatitis by Inhibiting HMGB1-TLR Expression and Down-Regulating the Nuclear Factor Kappa B Pathway. Inflammation 39: 96-106.

199. Chen M, Cao L, Luo Y, Feng X, Sun L, et al. (2015) Paeoniflorin protects against concanavalin A-induced hepatitis in mice. Int Immunopharmacol 24: 42-49.

200.Wang C, Nie H, Li K, Zhang YX, Yang F, et al. (2012) Curcumin inhibits HMGB1 releasing and attenuates concanavalin A-induced hepatitis in mice. Eur J Pharmacol 697: 152-157.

201.Fukuda T, Mogami A, Hisadome M, Komatsu HCO (2005) Therapeutic administration of $\mathrm{Y}-40138$, a multiple cytokine modulator, inhibits concanavalin A-induced hepatitis in mice. Eur J Pharmacol 523: 137-142. 